\title{
Minimal Invasive Aortic Valve Replacement by Upper Ministernotomy Approach in Comparison to The Conventional Full Median Sternotomy Approach
}

Hosam Fouad Fawzy, Khaled Abdel All, Mohsen Saber, Ayman Abdelmotelb

Department of Cardiothoracic Surgery, Faculty of medicine, Sohag University (Sohag), Egypt

*Corresponding author: Ayman Abdelmotelb, Mobile: (+20)01029454892, E-Mail: aymanabdelmotelb86@gmail.com

\begin{abstract}
Background: Minimal invasive cardiac surgery has gained more popularity nowadays in field of cardiac surgery due to the rapid progress in equipments and techniques in this field. Ministernotomy technique for aortic valve replacement is one of the most common minimal invasive cardiac surgery techniques.

Objective: Our study aimed to evaluate the advantages and disadvantages of using minimal invasive upper ministernotmy approach versus conventional full median sternotomy approach for aortic valve replacement.

Patients and methods: The study include 60 aortic valve replacement patients done from 2017 to 2019 in Sohag University Hospitals, Egypt and Hero Heart Institute, India. 30 patients by using conventional full sternotomy approach (group A), and 30 patients by using upper ministernotomy approach with central cannulation (Group B). Operative and post-operative data were compared. Results: Total operation time, ventilation time, ICU stay and total hospital stay, were significantly longer in conventional group (group A). Total bypass and cross clamp time were significantly longer in ministernotomy group (group B). Post-operative wound infection was significantly higher in conventional group (group A). Wound cosmoses post-operatively was better in ministernotmy group as regards patient opinion. Postoperative echocardiography showed no significant difference in post-operative pericardial effusion between both groups. Post-operative pain as well as early morbidity were significantly less in ministernotomy group (Group B). No mortality occurred in both groups. Conclusion: Upper ministernotomy is safe approach for aortic valve replacement and show advantages over conventional full sternotomy in form of shorter operative time, shorter hospital and ICU stay, better wound cosmetics, less post-operative bleeding and less post-operative pain.
\end{abstract}

Keywords: Cardiac surgery, Ministernotomy, Aortic valve replacement.

\section{INTRODUCTION}

Modern cardiac surgery that has been based on cardiopulmonary bypass (CPB), myocardial protection and median sternotomy. The median sternotomy incision provides simultaneous access to all cardiac valves and coronary arteries. Good exposure has been a necessity for the extensive corrections needed to treat for complex heart disease of most patients requiring cardiac operations (1). The aims of less invasive procedures are to maintain the effectiveness of the operation, decrease patient suffering, minimize cost, improve patient recovery, shorten intensive care and hospital stay and cosmetic for the patient. These potential benefits encourage application of minimally invasive cardiac valve surgery with further refinement of techniques; the minimally invasive approach can be applied to many cardiac surgical procedures ${ }^{(2)}$. Direct-vision minimally invasive valve surgery and (minimal access valve operations) were based on modifications of previous incisions, and nearly all were done under direct vision.

In 1996, the first minimally invasive aortic operations were done ${ }^{(3)}$. A minimally invasive procedure for performing repair or replacement of the aortic valve simplifies the technique and reduce surgical trauma ${ }^{(4)}$.In early 1996, working in Malaysia, the Stanford group performed the first four minimally invasive mitral valve replacements using end aortic balloon occlusion (Portaccess) with cardioplegia ${ }^{(5)}$. Surgeons found also that minimal access incisions provided adequate exposure of the aortic and mitral valves. Using ministernal or parasternal incisions, Gundry et al. (6) first showed encouraging valve surgery results with a low surgical mortality (1 to $3 \%$ ). This study aimed to evaluate the advantages and disadvantages of using upper ministernomy approach versus conventional full median sternotomy approach for aortic valve replacement.

\section{PATIENTS AND METHODS}

This study was designed to be a prospective, nonrandomized controlled one. It was conducted in the Department of Cardiothoracic Surgery at Sohag University Hospitals in Egypt and Hero DMC Heart Institute in India for a period of two years from 2017 to 2019. Sixty patients that were undergoing aortic valve replacement were included in the study: 30 patients were assigned to group (I) which was the conventional aortic valve replacement (median sternotomy) group. The other 30 patients were assigned to group (II) which was minimally invasive (upper mini-sternotomy) aortic valve replacement group.

Inclusion criteria: All patients were above 18 years old of both genders with indications for isolated aortic valve replacement surgery.

Exclusion criteria: General criteria (bad renal function, hepatic impairment). Cardiac condition (Patient with other cardiac disease: ischemic heart disease, mitral valve disease, aneurysm of the ascending aorta, poor ejection fraction (less than 40), pecuts excavatum, patient with history of pericarditis and patient with previous valve replacement). 


\section{Preoperative study:}

- Detailed history was taken and the patient's complaint was analyzed. History of rheumatic fever, congestive heart failure, infective endocarditis, embolic manifestations, drug therapy, drug allergy and previous cardiac operations.

- Complete clinical examination was performed for each patient, both general, and cardiac to detect, signs of heart failure, arrhythmia and infective endocarditis.

- Laboratory investigations: hematological study (complete blood picture, sedimentation rate, clotting and bleeding times and blood grouping) biochemical study [liver function tests (total and direct bilirubin, serum albumin, SGOT, SGPT, and prothrombin time), renal function tests (blood urea, and serum creatinine) and fasting blood sugar, and electrolytes].

- Resting 12-lead ECG was performed, and examined for rate, rhythm, and chamber enlargement or hypertrophy.

- Plain chest X-ray was done, and examined for the cardiothoracic ratio $\mathrm{C} / \mathrm{T}$ ratio.

- Transthoracic echocardiographic study.

\section{Surgical Technique:}

Group A (Conventional):

The standard approach, we used a vertical midline skin incision began at or below the sternal notch by 1-2 centimeters extending to at least the xiphoid tip and often few centimeters below it. Standard CPB at $32^{\circ} \mathrm{C}$, twostage venous cannula and aortic valve was replaced using horizontal mattress interrupted suture pattern. After deairing, aortic cross clamp was removed and weaning of bypass as usual began.

Group (B) (Mini-strenotomy):

Limited skin incision $(8-10 \mathrm{~cm})$ was made starting halfway between the sternal notch and manubrium and partial upper sternotomy was performed extending into the right fourth intercostal space. The CPB was then established by cannulation of the distal ascending aorta and the right atrium. Aortic cross-clamp was performed with an aortic clamp, which allows an unobstructed view of the operative field. Myocardial arrest was accomplished with the use of cold ante grade cardioplegia through the aortic root and aortic valve was replaced using horizontal mattress interrupted suture pattern. The patient was weaned from CPB and the heart was deaired through the vent in the ascending aorta.

Operative recorded data: Total time of operation (skin incision time to skin closing time), bypass time (on bypass time to off bypass time) and aortic cross clamp time (cross clamp on to cross clamp off time).

Post-operative data: Post-operative ventilation time (Calculation the time from starting of ventilation until extubation). Post-operative blood loss (by collection and calculation of the blood loss in the draining mediastinal and pleural tubes until their removal). Post-operative pain (using pain verbal rating scale from $0-10$, no pain 0 , mild1-3, mod 4-6 and severe7-10). Post-operative I.C.U. stay (Number of days in ICU). Post-operative hospital stay (Total patient stay in hospital from postoperative to discharge). Post-operative wound infection. Postoperative wound cosmoses (Patients were asked to evaluate subjectively the cosmetic effect of the incision). A numerical scale ranging from horrible to wonderful was used for this purpose: horrible- fair- good -very goodwonderful) ${ }^{(7)}$. Post-operative Echocardiography (All patients had post-operative echocardiography to evaluate prosthetic valve function, ejection fraction and to exclude presence of pericardial effusion). Early morbidity and mortality were recorded. Follow up echo after 1 and 6 months (All patients had follow up echocardiography to evaluate valve function and ejection fraction at 1 and 6 months postoperative).

\section{Ethical consent:}

An approval of the study was obtained from Sohag University academic and ethical committee. Every patient signed an informed written consent for acceptance of the operation. This work has been carried out in accordance with The Code of Ethics of the World Medical Association (Declaration of Helsinki) for studies involving humans.

\section{Statistical analysis}

The collected data were coded, processed and analyzed using the SPSS (Statistical Package for Social Sciences) version 22 for Windows ${ }^{\circledR}$ (IBM SPSS Inc, Chicago, IL, USA). Data were tested for normal distribution using the Shapiro Walk test. Qualitative data were represented as frequencies and relative percentages. Chi square test $(\chi 2)$ to calculate difference between two or more groups of qualitative variables. Quantitative data were expressed as mean \pm SD (Standard deviation). Independent samples t-test was used to compare between two independent groups of normally distributed variables (parametric data). $\mathrm{P}$ value $<0.05$ was considered significant.

\section{RESULTS}

Sex: In group (A), the total number of the patients were 30 patients, 25 males $(83.3 \%)$ and 5 females (16.7\%), and in group (B), the total number of the patients were 30 patients, 26 male $(86.7 \%)$ and 4 female $(13.3 \%)$. Age: In group (A), the age ranged from 18-55 years (Mean 25.73 $\pm 5.95 \mathrm{Y}$ ) and in group (B) the age ranged from 17-50 years (Mean $22.38 \pm 4.57 \mathrm{Y}$ ) (Table 1).

Table (1): Demographic data between both groups

\begin{tabular}{|c|c|c|}
\hline Group & Age & Sex \\
\hline Group(A) & $18: 55$ years & 25 male $(83.3 \%)$ \\
& (Mean 25.73 $\pm 5.95 \mathrm{Y})$ & 5 female $(16.7 \%)$ \\
\hline Group(B) & $17: 50$ years & 26 male $(86.7 \%)$ \\
& (Mean 22.38 $\pm 4.57 \mathrm{Y})$ & 4 female $(13.3 \%)$ \\
\hline
\end{tabular}

Table (2) showed that total operation time was significantly longer in conventional group (group A), while total bypass time and cross clamp time were significantly longer in ministernotomy group (group B). Additionally, ventilation time, total hospital stay and total blood loss postoperatively were significantly longer in conventional group (group A). While, ICU stay was slightly longer in conventional group (group A). 
Table (2): Comparison between total operative time, total bypass time, cross clamp time, ventilation time, ICU stay, total hospital stay and total blood loss between both groups

\begin{tabular}{|c|c|c|c|c|c|c|c|c|c|c|c|c|c|c|}
\hline \multirow{2}{*}{ Group } & \multicolumn{2}{|c|}{$\begin{array}{c}\text { Total } \\
\text { operation } \\
\text { time }\end{array}$} & \multicolumn{2}{|c|}{$\begin{array}{c}\text { Total } \\
\text { bypass } \\
\text { time }\end{array}$} & \multicolumn{2}{|c|}{$\begin{array}{c}\text { Cross } \\
\text { clamp } \\
\text { time }\end{array}$} & \multicolumn{2}{|c|}{$\begin{array}{c}\text { Ventilation } \\
\text { time }\end{array}$} & \multicolumn{2}{|c|}{ ICU stay } & \multicolumn{2}{|c|}{$\begin{array}{c}\text { Total } \\
\text { Hospital } \\
\text { stay }\end{array}$} & \multicolumn{2}{|c|}{$\begin{array}{c}\text { Total } \\
\text { blood loss }\end{array}$} \\
\hline & $\mathrm{A}$ & $\mathrm{B}$ & $\mathrm{A}$ & B & $\mathrm{A}$ & B & A & B & A & B & $\mathrm{A}$ & B & A & B \\
\hline Minimum & 200 & 140 & 70 & 76 & 40 & 45 & 5 & 3 & 2 & 2 & 6 & 5 & 200 & 100 \\
\hline Maximum & 215 & 180 & 80 & 82 & 70 & 72 & 12 & 7 & 6 & 5 & 12 & 8 & 1200 & 550 \\
\hline Median & 210 & 152 & 76 & 78 & 60 & 61 & 7 & 5 & 3 & 2 & 7 & 5 & 300 & 300 \\
\hline Mean & 209 & 155 & 76,2 & 78,1 & 56,7 & 60,2 & 7,5 & 5 & 2,9 & 2,27 & 7,6 & 5,53 & 447 & 290 \\
\hline $\begin{array}{l}\text { Standard } \\
\text { deviation }\end{array}$ & 4,79 & 10,5 & 2,47 & 1,5 & 8,46 & 7,9 & 1,89 & 1,29 & 1,2 &, 78 & 1.6 &, 81 & 150 & 115 \\
\hline $\mathrm{P}$ value & \multicolumn{2}{|c|}{0001} & \multicolumn{2}{|c|}{.0006} & \multicolumn{2}{|l|}{011} & \multicolumn{2}{|l|}{0001} & \multicolumn{2}{|c|}{014} & \multicolumn{2}{|c|}{.0001} & \multicolumn{2}{|l|}{001} \\
\hline
\end{tabular}

Post-operative wound infection was significantly higher in conventional group (group A)(Table 3 ).

Table (3): Comparison of post-operative wound infection between both groups

\begin{tabular}{|c|c|c|c|}
\hline \multirow{2}{*}{ Post-Operative wound infection } & \multicolumn{2}{|c|}{ Patients group } & \multirow{2}{*}{ Total } \\
\hline & Group (A) & Group (B) & \\
\hline $\begin{array}{l}\text { Yes } \\
\text { Count } \\
\text { \% within patient Group }\end{array}$ & $\begin{array}{c}4 \\
13.3 \%\end{array}$ & $\begin{array}{c}1 \\
3.3 \%\end{array}$ & $\begin{array}{c}5 \\
8,3 \%\end{array}$ \\
\hline $\begin{array}{l}\text { No } \\
\text { Count } \\
\% \text { within patient group }\end{array}$ & $\begin{array}{c}26 \\
86.7 \%\end{array}$ & $\begin{array}{c}29 \\
96.6 \% \\
\end{array}$ & $\begin{array}{c}55 \\
91.6 \% \\
\end{array}$ \\
\hline $\begin{array}{l}\text { Total } \\
\text { Count } \\
\% \text { within patient group }\end{array}$ & $\begin{array}{c}30 \\
100.0 \%\end{array}$ & $\begin{array}{c}30 \\
100.0 \%\end{array}$ & $\begin{array}{c}60 \\
100.0 \%\end{array}$ \\
\hline
\end{tabular}

Regarding patient opinion, wound cosmoses post-operatively was better in ministernotmy group (Table 4).

Table (4): Comparison of post-operative wound cosmetics between both groups

\begin{tabular}{|l|c|c|c|}
\hline $\begin{array}{c}\text { Wound cosmoses as regard patient } \\
\text { point of view }\end{array}$ & Group (A) & Group (B) & $\begin{array}{c}\text { Total number and percentage } \\
\text { in total patients }\end{array}$ \\
\hline $\begin{array}{l}\text { HORRIBLE } \\
\text { \% within patient Group }\end{array}$ & 2 & 0 & 2 \\
\hline FAIR & $6.6 \%$ & $0 \%$ & $3.3 \%$ \\
\hline G within patient Group & 18 & 0 & 18 \\
\hline GOOD & $60 \%$ & $\%$ & $30 \%$ \\
\hline VERY GOTh patient Group & 10 & 15 & 25 \\
\% within patient Group & $33.3 \%$ & $50 \%$ & $41.6 \%$ \\
\hline WONDERFULL & 0 & 10 & 10 \\
\% within patient Group & $0 \%$ & $33,3 \%$ & $5.6 \%$ \\
\hline
\end{tabular}

Post-operative echocardiography showed no significant difference in post-operative pericardial effusion between both groups as shown in table (5).

Table (5): Comparison of post-operative pericardial effusion between both groups

\begin{tabular}{|l|c|c|c|}
\hline $\begin{array}{c}\text { Post-operative pericardial } \\
\text { effusion }\end{array}$ & Group (A) & Group (B) & $\begin{array}{c}\text { Total number and percentage } \\
\text { in total patients }\end{array}$ \\
\hline $\begin{array}{l}\text { NO } \\
\text { \% within patient Group }\end{array}$ & 25 & 25 & 50 \\
\hline MILD & $83,3 \%$ & $83,3 \%$ & $83,3 \%$ \\
\hline \% within patient Group & 4 & 5 & 9 \\
\hline MODERATE & $13,3 \%$ & $16,6 \%$ & $15 \%$ \\
\hline MASSIVE & 1 & 0 & 1 \\
\% within patient Group & $3,3 \%$ & $0 \%$ & $1,6 \%$ \\
\hline
\end{tabular}


Table (6) showed that post-operative pain was significantly less in ministernotomy group (group B).

Table (6): Comparison of degree of post-operative pain between both groups

\begin{tabular}{|l|c|c|c|c|}
\hline Post-operative pain & $\begin{array}{c}\text { Group (A) } \\
\mathbf{1}^{\text {st }} \text { day }\end{array}$ & $\begin{array}{c}\text { Group (A) } \\
\text { last day before } \\
\text { discharge }\end{array}$ & $\begin{array}{c}\text { Group (B) } \\
\mathbf{1}^{\text {st }} \text { day }\end{array}$ & $\begin{array}{c}\text { Group (B) } \\
\text { last day before } \\
\text { discharge }\end{array}$ \\
\hline $\begin{array}{l}\text { NO } \\
\text { \% within patient } \\
\text { Group }\end{array}$ & 0 & 2 & 0 & 6 \\
\hline $\begin{array}{l}\text { MILD } \\
\text { \% within patient } \\
\text { Group }\end{array}$ & $0 \%$ & $6,6 \%$ & $0 \%$ & $20 \%$ \\
\hline $\begin{array}{l}\text { MODERATE } \\
\text { \% within patient } \\
\text { Group }\end{array}$ & 10 & 26 & 16 & 24 \\
\hline $\begin{array}{l}\text { SEVERE } \\
\text { \% within patient } \\
\text { Group }\end{array}$ & $\begin{array}{c}2,3 \% \\
6,6 \%\end{array}$ & 2 & $53,3 \%$ & $80 \%$ \\
\hline
\end{tabular}

Table (7) showed that early morbidity was significantly less in ministernotomy group (group B).

Table (7): Comparison of early morbidity between both groups

\begin{tabular}{|l|c|c|c|}
\hline \multicolumn{1}{|c|}{ Early morbidity } & Group (A) & Group (B) & $\begin{array}{c}\text { Total number and } \\
\text { percentage in total } \\
\text { patients }\end{array}$ \\
\hline $\begin{array}{l}\text { Re exploration for } \\
\text { bleeding } \\
\text { \% within patient group }\end{array}$ & 1 & 0 & 1 \\
\hline $\begin{array}{l}\text { Atrial fibrillation } \\
\text { development } \\
\text { \% within patient group }\end{array}$ & $2.3 \%$ & $0 \%$ & $1.6 \%$ \\
\hline
\end{tabular}

No mortality occurred in both groups.

\section{DISCUSSION}

In our study, total time of operation was significantly shorter in ministernomy group that may be related to the smaller size of incision, which took shorter time in closure and shorter time of hemostasis in comparison with the conventional group.

Total bypass time and cross clamp time was longer in ministernotomy group, mostly because of slightly limited exposure and difficulty of deairing compared to the conventional group. In meta-analysis study done on 26 studies to compare both techniques, it also showed longer total bypass time and cross clamp time in ministernotomy group ${ }^{(8)}$.

Ventilation time was shorter in ministernotomy group. In meta-analysis study done on 26 studies to compare both techniques, it showed shorter ventilation time in ministernotomy group and pooled WMD (weighed mean difference) of -2.71 minutes $(95 \%$ CI -3.80 to -1.62$)$. Shorter ventilation time may be related to the shorter total operative time in ministernotomy group with subsequent less doses of anaesthetic drugs. In addition, less pain with ministernotomy group and less tissue trauma add to the earlier recovery ${ }^{(8)}$.

Total hospital stay and ICU stay were shorter in ministernotomy group. This is important result, as most of patients did not want longer hospital stay. This was considered one of the most important advantages of ministernotomy technique from patient point of view. Compared to results of meta-analysis study conducted by Brown et al. ${ }^{(8)}$, ICU stay was slightly shorter in the partial upper sternotomy group, with a WMD of -0.46 days $(95 \% \mathrm{CI}-0.72$ to -0.20 days and hospital stay was shorter in the ministernotomy group in the overall pooled WMD ( -0.91 days, $95 \% \mathrm{CI}-1.45$ to -0.37 days ${ }^{(8)}$.

Post-operative bleeding was significantly less in ministernotomy group than in conventional group. This is in agreement with Brown et al. ${ }^{(8)}$. The WMD was $-79.37 \mathrm{~mL}(95 \% \mathrm{CI}-135.78$ to -22.96$)$ in favour of the partial upper sternotomy group ${ }^{(8)}$. Decreased blood loss may be related to a decrease in surgical trauma and less tissue trauma ${ }^{(9)}$. It is important to note that blood loss through the chest tube is not the best clinical endpoint. However, because the fluid collected in chest tubes may be a combination of blood and other fluids and may not be consistently measured ${ }^{(\mathbf{1 0})}$. A more clinically useful endpoint would be the rate of blood transfusion according structured protocols such as those proposed in the recent clinical guidelines from the Society of Thoracic Surgeons and The Society of Cardiovascular Anaesthesiologists ${ }^{\mathbf{( 1 1})}$.

Our study showed that patients had lower amount of pain after a ministernotomy. This may be due 
to the lesser stretching of the sternum required in a partial sternotomy. In addition, the presence or absence of sternal fractures may play an important role in early postoperative pain levels. Additionally, we have drawback in our study that actually pain management was not standardized for all patients ${ }^{(\mathbf{1 2})}$.

Wound cosmoses post-operatively was better in ministernotmy group as regards patient' opinion. Same result was reported by meta-analysis study done by Brown et al. (8). The shorter skin incision of ministernotomy may intuitively appear more cosmetic. Younger patients especially young females were more concerned about the cosmetic result.

Wound infection was significantly less in ministernotomy group, mostly related to decrease in surgical trauma and less exposure area in operative field.

Morbidity was higher in conventional full sternotomy group in form of re-exploration for bleeding, atrial fibrillation post-operatively. This may be related to the more surgical trauma of full sternotomy incision, the longer time of operation and the longer post-operative hospital stay ${ }^{(13)}$.

Post-operative echocardiography after 1and 6 months showed no significant difference between both groups. In our study as regards valve prosthesis function, ejection fraction difference between pre- and postoperative echo and paravalvular leak incidence showed no effect. We think this is actually related to the fact that either ministernotomy or conventional sternotomy do not widely affect the exposure of the aortic valve during operation hence have no effect on valve prosthesis function post-operative.

In our study, there was no need to convert any of ministernotomy cases to conventional sternotomy. This may be related to our good selection of the cases with good ejection fraction preoperative and no associated cardiac conditions.

In our study, we had no right internal mammary injury during ministernotomy incision this may be related to our technique to use an artery or mosquito forceps at lateral border of sternum during making the $\mathrm{J}$ ministernotomy to protect the right internal mammary artery from injury .

Both groups showed NYHA classification range from grade (I) to grade (II) six months postoperatively with no significant difference between both groups. This actually showed that the difference in technique did not have much effect on the long-term NYHA classification or symptoms of patients.

Both groups show zero mortality. this also give important idea that difference in approach did not affect mortality or increase it.

\section{CONCLUSION}

Our study showed that less invasive partial upper sternotomy for aortic valve replacement can be performed safely, without any increase in risk of death or other major complications. Moreover, there were many advantages of ministernotomy technique over the conventional full sternotomy technique, as ministernotomy showed statistically significant less operation time, ventilation time, ICU stay, hospital stay and less post-operative bleeding. Besides, our study showed that ministernotomy technique had better cosmetic results and less amount of post-operative pain compared to conventional full sternotomy technique.

\section{Financial support and sponsorship: Nil. \\ Conflict of Interest: Nil.}

\section{REFERENCES}

1. Lytle B (1996): Minimally invasive cardiac surgery. J Thorac Cardiovasc Surg., 111: 554-5.

2. Tam R, Almeida A (1998): Minimally invasive aortic valve replacement via partial sternotomy. Ann Thorac Surg., 65: 275-276.

3. Cohn L, Adams D, Couper G et al. (1997): Minimally invasive cardiac valve surgery improves patient satisfaction while reducing costs of cardiac valve replacement and repair. Ann Surg., 226: 421-6.

4. Cosgrove D, Sabik J, Navia J (1998): Minimally invasive valve operations. Ann. Thorac Surg., 65: 1535 1539.

5. Pompili M, Stevens J, Burdon T (1996): Port-access mitral valve replacement in dogs. J Thorac Cardiovasc Surg., 112: 1268-74.

6. Gaundry S, Shattuck O, Razzouk A (1998): Facile minimally invasive cardiac surgery via ministernotomy. Ann Thorac Surg., 65:1100-1104.

7. Aris A, Camara M, Montiel J et al. (1999): Ministernotomy versus median sternotomy for aortic valve replacement: a prospective randomized study. Ann Thorac Surg., 67: 1583-7.

8. Brown M, McKellar S, Sundt $T$ et al. (2009): Ministernotomy versus conventional sternotomy for aortic valve replacement: a systematic review and metaanalysis. J Thorac Cardiovasc Surg., 137: 670-679.

9. Vukovic P, Milojevic P, Stojanovic I et al. (2019): The role of ministernotomy in aortic valve surgery-a prospective randomized study. J Card Surg., 34: 435-9.

10. Aliahmed H, Karalius R, Valaika A et al. (2018): Efficacy of Aortic Valve Replacement through Full Sternotomy and Minimal Invasion (Ministernotomy). http://europepmc.org/article/PMC/6037263

11. Hassan M, Miao Y, Maraey A et al. (2015): Minimally Invasive Aortic Valve Replacement: Cost-Benefit Analysis of Ministernotomy Versus Minithoracotomy Approach. J Heart Valve Dis., 24 (5): 531-9.

12. Di Bacco L, Miceli A, Glauber M (2015): Minimally invasive aortic valve surgery. J Thorac Dis., 13 (3): 19451959.

13. Klop I, van Putte B, Kloppenburg G et al. (2012): Comparing quality of life and postoperative pain after limited access and conventional aortic valve replacement: Design and rationale of the LImited access aortic valve replacement (LIAR) trial. Contemp Clin Trials Commun., 21:100700. DOI:10.1016/j.conctc.2021.100700 